\title{
Evaluation of the antiplasmodial and leishmanicidal potential of Myrciaria dubia (Myrtaceae) extract
}

\author{
Vanessa Carolina de Sena Correia ${ }^{[1],[2],}$ Nathália Oliveira Lima ${ }^{[2],}$ \\ Flávio Augusto de Souza Oliveira ${ }^{[3]}$, Ana Paula de Azevedo dos Santos ${ }^{[3]}$, \\ Carolina Bioni Garcia Teles ${ }^{[3]}$, Waldesse Piragé de Oliveira Júnior ${ }^{[2]}$ \\ and Raphael Sanzio Pimenta ${ }^{[1]}$
}

\begin{abstract}
[1]. Laboratório de Microbiologia Geral e Aplicada, Universidade Federal do Tocantins, Palmas, Tocantins, Brasil. [2]. Laboratório de Biotecnologia, Universidade Federal do Tocantins, Palmas, Tocantins, Brasil. [3]. Laboratório da Plataforma de Bioensaios de Malária e Leishmaniose, Fundação Oswaldo Cruz, Porto Velho, Rondônia, Brasil,
\end{abstract}

\begin{abstract}
Introduction: Malaria and leishmaniasis are prevalent in tropical regions, which have environmental characteristics that are highly favorable to protozoa and vectors of these diseases; the transmission of these infections in sub-tropical regions, although recognized, represents only a small fraction of cases. Plants are constantly being used in the search for and acquisition of new drugs, and many compounds derived from them have been used to combat various diseases. In this study, we evaluated the action of the dichloromethanolic extract of Myrciaria dubia leaves against the protozoa Plasmodium falciparum, Leishmania amazonensis, Leishmania braziliensis, and Leishmania chagasi through bioassays. Methods: The extract from M. dubia was tested for its anti-P. falciparum activity in an anti-histidine-rich protein II immunosorbent assay. The antileishmanial assays were performed using the resazurin method, while cytotoxicity against human hepatoma (HepG2) strain was determined using the colorimetric MTT [3-(4, 5-dimethyl-2- thiazolyl)-2, 5-diphenyl-2H tetrazolium bromide] method. Results: The M. dubia extract presented a half-maximal inhibitory concentration equal to $2.35(1.05) \mu \mathrm{g} / \mathrm{mL}$ for P. falciparum, 190.73 (6.41) $\mu \mathrm{g} / \mathrm{mL}$ for L. amazonensis, and greater than equal to $200 \mu \mathrm{g} / \mathrm{mL}$ for L. chagasi and L. braziliensis strains. The cytotoxic concentration for $50 \%$ of the cells was above $500 \mu \mathrm{g} / \mathrm{mL}$ for $\mathrm{HepG} 2$, indicating no toxicity and greater selectivity against parasites. Conclusions: The results obtained indicate the presence of antiplasmodial and leishmanicidal bioactive compounds in the dichloromethanolic extracts of M. dubia leaves, and point towards future studies to elucidate the mechanism of action for each physiological effect.
\end{abstract}

Keywords: Plasmodium falciparum. Leishmania spp. Camu-camu. Canguçu.

\section{INTRODUCTION}

Malaria is endemic in 95 countries, with high prevalence in mainly tropical and subtropical countries situated south of the Sahara desert, in Southeast Asia, Latin America, and the Caribbean, particularly those located in the Amazon Basin region ${ }^{(1)}$. It is a parasitic disease, with four causative agents, all of which are protozoa belonging to the genus Plasmodium (Plasmodium vivax, Plasmodium ovale, Plasmodium malariae, and Plasmodium falciparum) ${ }^{(2)}$. P. falciparum is the most widely studied since it causes the highest number of deaths. Natural malaria transmission occurs through the bite of female mosquitoes from the Anopheles genus, with the most frequent species in Brazil being Anopheles darlingi $i^{(3)}$.

Corresponding author: MSc. Vanessa Carolina de Sena Correia.

e-mail:vcscbio@gmail.com

Received 3 June 2016

Accepted 8 September 2016
Leishmaniasis is an infectious disease caused by protozoa of the genus Leishmania. It is endemic in 98 countries, with an estimated 50,000 deaths per year, ranking ninth among infectious diseases. It presents high levels of endemicity, morbidity, and mortality in populations in Africa, Asia, the Middle East, the Mediterranean region, and Latin America ${ }^{(4)}$. These diseases are transmitted to humans and other mammals through the bite of the female insect Lutzomyia spp $^{(5)}$.

Leishmaniasis may present diverse clinical manifestations, affecting the skin, mucous membranes, and internal organs. Cutaneous leishmaniasis may be caused by fourteen Leishmania species. Diffuse leishmaniasis is caused by Leishmania (Leishmania) amazonensis, the mucocutaneous form is mainly caused by Leishmania (Viannia) braziliensis, and visceral leishmaniasis is a parasitic disease involving the Leishmania donovani complex, caused by Leishmania (Leishmania) chagasi in Brazil ${ }^{(6)}$.

Given the increasing need to obtain and develop new drugs for the treatment and control of diseases for which there is still 
no treatment and/or satisfactory cure, natural plant products may be very useful ${ }^{(7)}$. In the Amazon, many plants are used for therapeutic purposes. These are sometimes the only source of medicine, particularly in isolated and distant places ${ }^{(8)}$.

Camu-camu (Myrciaria dubia McVaugh) is a medicinal plant native to the Amazon rainforest, known for its high levels of ascorbic acid, carotenoids, potassium, and polyphenols, such as flavonoids and ellagitannins ${ }^{(9)(10)(11)(12)}$. The main economic characteristic of this fruit is related to its high ascorbic acid content, which helps combat and prevent the formation of free radicals, making it useful against colds, pulmonary disorders, bladder irregularities, low immunity, and early or natural $\operatorname{aging}^{(13)(14)}$.

Myoda et al. ${ }^{(15)}$ studied the effects of the methanol extract from the seeds and peel of M. dubia against the following microorganisms: Staphylococcus aureus, Escherichia coli, and Saccharomyces cerevisiae, proposing that the lipophilic and phenolic compounds present in the camu-camu extract are responsible for its antimicrobial activity. Given the phytotherapeutic potential of $M$. dubia, the objective of this study was to evaluate the action of the dichloromethanolic extract obtained from the leaves of M. dubia through bioassays against the protozoa Plasmodium falciparum and promastigote forms of Leishmania amazonensis, Leishmania braziliensis, and Leishmania chagasi.

\section{METHODS}

\section{Collection of plant material}

Samples of M. dubia were collected in August 2012, from along the banks of the river Javaés $\left(09^{\circ} 32^{\prime} \mathrm{S}, 50^{\circ} 01^{\prime} \mathrm{W}\right)$, in the municipality of Pium, Tocantins, Brazil. The location of the samples was georeferenced by global positioning system (GPS), and the samples were preserved, identified, and registered (registration no. 10.592) in the Herbarium at the Federal University of Tocantins, Porto Nacional Campus.

\section{Preparation and dilution of the Myrciaria dubia crude extract}

The M. dubia extract was prepared using P.A. (Vetec) as a dichloromethane solvent, following the protocol proposed by Rosa et al. ${ }^{(16)}$. The extract was diluted in $0.5 \%$ dimethyl sulfoxide (DMSO) solvent, at varying concentrations $(500-1.56 \mu \mathrm{g} / \mathrm{mL})$ for the bioassays.

\section{Continuous cultivation of the erythrocytic phase of the parasite Plasmodium falciparum}

In the antimalarial activity assays, sanguineous forms of a chloroquine (CQ)-resistant Plasmodium falciparum clone W2 were used. Parasites were cultured in O-type $\mathrm{Rh}^{+}$human red blood cells with $2 \%$ hematocrit and $50 \mathrm{mg} / \mathrm{mL}$ albumax (Gibco) under the conditions established by Trager and Jensen $^{(17)}$. To this end, the parasites were grown in Roswell Park Memorial Institute (RPMI) 1640 (Sigma-Aldrich) culture medium supplemented with $25 \mathrm{mM}$ (4-(2-hydroxyethyl)1-piperazineethanesulfonic acid) Hepes (Sigma-Aldrich), $21 \mathrm{mM}$ sodium bicarbonate (Sigma-Aldrich), $11 \mathrm{mM}$ glucose
(Sigma-Aldrich) and $40 \mu \mathrm{g} / \mathrm{mL}$ gentamicin, and then maintained at $37^{\circ} \mathrm{C}$ under a gaseous mixture containing $5 \% \mathrm{CO}_{2}, 5 \% \mathrm{O}_{2}$ and $90 \%$ balanced $\mathrm{N}_{2}$. The development of the parasites was monitored by daily observation of blood smears stained with Giemsa and analyzed using light microscopy.

\section{Synchronization of parasites for use in in vitro tests}

The cultures predominantly composed of rings (young trophozoites) used in chemotherapy trials were subjected to a synchronization process with sorbitol, as described by Lambros and Vanderberg ${ }^{(18)}$.

\section{Preparation of the plates for chemotherapy trials}

Synchronized parasite cultures were distributed in 96-well microtiter plates by adding $180 \mu \mathrm{L}$ of RPMI culture medium containing $0.05 \%$ parasitemia and $1.5 \%$ hematocrit to each well. Initially, $20 \mu \mathrm{L}$ of the extract, in triplicate, and in serial concentrations from 100 to $0.097 \mu \mathrm{g} / \mathrm{mL}$ were added to the culture plate. The control wells (six per assay) contained infected red blood cells with no added test compounds (negative control). The standard antimalarial drug, artemisinin (ART), was tested in parallel as the positive control in all the experiments in serial dilutions from 50 to $0.7812 \mathrm{ng} / \mathrm{mL}$.

The plates were maintained for $72 \mathrm{~h}$ under ideal conditions for the development of Plasmodium. After this period the plates were frozen at $-80^{\circ} \mathrm{C}$ and thawed twice to lyse the erythrocytes $^{(19)}$.

\section{Anti-HRP II enzyme immunoassay}

The anti- histidine-rich protein II (HRP II) enzyme immunoassay followed the protocol adopted by Noedl et al. ${ }^{(20)}$. In this test, the commercial monoclonal primary antibody (Mouse IgM anti-Plasmodium falciparum HRP II - Monoclonal) MPFM-55A (ICLLAB) was used at $1 \mu \mathrm{g} / \mathrm{mL}$ to sensitize the plates (Maxysorp Nunc). After sensitization, $200 \mu \mathrm{L}$ of a blocking solution ( $2 \%$ PBS-BSA) was added to each well and the plate was incubated at room temperature for $2 \mathrm{~h}$. After washing thrice in PBS-Tween $20(0.05 \%$ PBS-T), $100 \mu \mathrm{L}$ of hemolyzed P. falciparum culture samples was added to each well. The plate was incubated for $1 \mathrm{~h}$ at room temperature in a humid chamber, then washed three times with PBS-T, and incubated with the secondary antibody MPFG55P (ICLLAB) (1:5.000) for $1 \mathrm{~h}$ in the same conditions as mentioned above. Once again, the plate was washed thrice in PBS-T and the reaction was revealed using $100 \mu \mathrm{L}$ of 3.3', 5, 5'-tetramethylbenzidine (TMB) solution for $5 \mathrm{~min}$. The reaction was stopped by adding $50 \mu \mathrm{L}$ per well of a $1 \mathrm{M}$ sulfuric acid solution. The optical density was determined using a microplate spectrophotometer (BIO-RAD Model 3550) with a wavelength of $450 \mathrm{~nm}$. Each assay was performed in triplicate, in three independent experiments.

Growth inhibition of $50 \%$ of the parasites $\left(\mathrm{IC}_{50}\right)$ was determined using dose-response curves, in non-linear regression function. The software Origin (OriginLab Corporation, Northampton, MA, USA) was used to determine the $\mathrm{IC}_{50}$ value. According to Reynertson et al. ${ }^{(21)}$, samples with $\mathrm{IC}_{50}$ less than $50 \mu \mathrm{g} / \mathrm{mL}$ are considered very active, $50-100 \mu \mathrm{g} / \mathrm{mL}$ moderately active, $100-200 \mu \mathrm{g} / \mathrm{mL}$ slightly active and a sample with a value above $200 \mu \mathrm{g} / \mathrm{mL}$ is considered inactive. 


\section{Cultivation of HepG2 cells}

The human hepatoma (HepG2) cell lines were cultured according to Calvo-Calle et al. ${ }^{(22)}$. They were maintained in culture bottles supplemented with RPMI containing 5\% fetal bovine serum (FBS) (Gibco/Invitrogen) and 40mg/L gentamycin (Schering-Plough). The cells were maintained in an incubator with $5 \% \mathrm{CO}_{2}$ at $95 \%$ humidity and $37{ }^{\circ} \mathrm{C}$. After a confluence of about $80 \%$ is attained, the cells were subcultured, or used to perform cytotoxicity assays.

\section{Cytotoxicity test}

Cytotoxicity was determined using the MTT (3-(4,5-dimethylthiazol-2-yl)-2,5-diphenyltetrazolium bromide) colorimetric method ${ }^{(23)}$. Cells were seeded at $2 \times 10^{4} /$ well and after $24 \mathrm{~h}$ of treatment with the M. dubia extract (500-7.8 $\mu \mathrm{g} / \mathrm{mL}), 20 \mu \mathrm{L}$ of MTT at a concentration of $5 \mathrm{mg} / \mathrm{mL}$ in PBS (w/v) was added to each well. The plate was left for $4 \mathrm{~h}$ in an incubator at $37^{\circ} \mathrm{C}$. At the end of this period, the culture medium along with the excess MTT was discarded, and then $100 \mu \mathrm{L}$ of DMSO (Sigma-Aldrich) was added to each well. The optical density was read using a microplate spectrophotometer at a wavelength of $570 \mathrm{~nm}$. Cells with no added extract were used as negative control.

The $50 \%$ cytotoxic concentration $\left(\mathrm{CC}_{50}\right)$ of the cells was determined from nonlinear regression of the serial dilutions of the extracts using the program Origin.

\section{Selectivity index}

The selectivity index (SI) of the samples was evaluated by calculating the ratio of the $\mathrm{CC}_{50}$ value and the $\mathrm{IC}_{50}$ value. Values greater than 10 were considered to indicate lack of toxicity, while substances with values below 10 were considered toxic ${ }^{(24)}$.

\section{Cultivation of the parasite Leishmania spp}

Strains of Leishmania amazonensis (IFLA/BR/67PH8), Leishmania braziliensis (IOCL 566) and L. chagasi (IOCL 579) were provided by Leishmania Collection from the Oswaldo Cruz Institute (CLIOC-RJ). Leishmania spp promastigote forms were cultured at $24^{\circ} \mathrm{C}$ in RPMI medium (SIGMA ${ }^{\circledR}$, St. Louis, MO, USA) supplemented with $20 \%$ FBS, $2 \mathrm{mM}$ L-glutamine, $20 \mathrm{mM}$ 4-(2-hydroxyethyl)-1-piperazineethanesulfonic acid (Hepes) and $40 \mu \mathrm{g} / \mathrm{mL}$ of Gentamycin (Sigma).

The promastigote cultures were maintained in vitro using a parasitic aliquot in stationary growth phase, which was diluted in erythrosin B dye $(0.04 \%)$. The concentration of the protozoa was estimated with the aid of a Neubauer chamber and adjusted to $1 \times 10^{6}$ promastigotes per $\mathrm{mL}$. The parasites that were stained red were considered dead and those that were birefringent and mobile were considered alive. Only the living parasites were quantified. Consequently, the parasites were placed in RPMI/FBS culture medium and maintained at $24^{\circ} \mathrm{C}$, and were subcultured every five days for up to eight passages.

\section{Evaluation of the leishmanicidal potential of the crude extract of Myrciaria dubia using the resazurin method}

Leishmania amazonensis, Leishmania braziliensis, and Leishmania chagasi promastigotes were plated $\left(1 \times 10^{6}\right.$ parasites/ well) in 96-well plates and incubated with concentrations ranging from 200 to $1.56 \mu \mathrm{g} / \mathrm{mL}$ of extract. Besides the control containing only parasites in culture medium, controls of the solvent $0.5 \%$ DMSO and the drug $(3 \mu \mathrm{g} / \mathrm{mL}$ pentamidine) were also used. The plate was incubated at $24^{\circ} \mathrm{C}$ for $72 \mathrm{~h}$. After this, $20 \mu \mathrm{L}$ of a $2 \mathrm{mM}$ resazurin solution was added to each well ${ }^{(25)}$. The plates were incubated for $4 \mathrm{~h}$, and the reduction of resazurin was determined by readings obtained from a fluorimeter (excitation wavelength of $485 \mathrm{~nm}$ and emission wavelength of $590 \mathrm{~nm}$ ). The control value (RPMI blank) was subtracted from all obtained values. In all, three independent assays were performed and the samples were tested in triplicate. The results were expressed as growth inhibition (GI) rate according to the formula: $\% \mathrm{GI}=100-[(\mathrm{A}-\mathrm{a}) /(\mathrm{B}-\mathrm{a})] \times 100$. Where: $A=$ Absorbance of treated cells; $a=$ Absorbance of white cells and $\mathrm{B}=$ Absorbance of control cells.

\section{RESULTS}

\section{Antiplasmodial activity}

All assays were performed in triplicate and the results were expressed as the average of the repetitions. The M. dubia extract showed anti-P. falciparum (chloroquine-resistant strain W2) activity in an enzyme-linked immunosorbent assay (ELISA) using anti-HRPII monoclonal antibodies, involving a specific protein from the parasite, and the results of the bioassays are shown in Table 1.

\section{TABLE 1}

Evaluation of the dichloromethanolic extract from Myrciaria dubia in relation to the $\mathrm{IC}_{50}$ (growth inhibition of $50 \%$ of the parasites), $\mathrm{CC}_{50}$ (cytotoxic concentration for $50 \%$ of the HepG2 cells), and SI (selectivity index).

\begin{tabular}{lccc}
\hline Protozoan & $\mathbf{I C}_{\mathbf{5 0}}(\boldsymbol{\sigma})(\boldsymbol{\mu g} / \mathbf{m L})$ & $\mathbf{C C}_{\mathbf{5 0}}(\boldsymbol{\mu g} / \mathbf{m L})$ & $\mathbf{S I}$ \\
\hline Plasmodium falciparum & $2.35(1.05)$ & $>500$ & 212.77 \\
Leishmania amazonensis & $190.73(6.41)$ & $>500$ & 2.6 \\
Leishmania braziliensis & $\geq 200$ & $>500$ & 2.5 \\
Leishmania chagasi & $\geq 200$ & $>500$ & 2.5 \\
\hline
\end{tabular}

HepG2: human hepatoma; $\mathbf{I C}_{50}: 50 \%$ inhibitory concentration; $\mathbf{C C}_{50}: 50 \%$ cytotoxic concentration; $\mathbf{S I}$ : selectivity index.

The positive control used in the antiplasmodial bioassay was artemisinin, $\mathrm{IC}_{50}=6.77 \mathrm{ng} / \mathrm{mL}$ (3.45). The compound used as the extract solvent $(0.5 \%$ DMSO) showed no antiplasmodial, leishmanicidal, or cytotoxic effect, excluding the possibility of the solvent acting as an inhibitory agent (data not shown).

Regarding the cytotoxic activity of the extracts on the cell line derived from human hepatoma (HepG2), assessed by the ability of cells to metabolize tetrazolium salt (MTT) to formazan, the cytotoxic concentration for $50 \%$ of the cell population $\left(\mathrm{CC}_{50}\right)$ was calculated based on a dose response. $\mathrm{CC}_{50}$ values above $500 \mu \mathrm{g} / \mathrm{mL}$ were observed in all repetitions, 
indicating that the compounds present in the plant extract did not present toxicity. The SI, considering the $\mathrm{IC}_{50}$ data for $P$. falciparum, was greater than 10 , confirming that the extract is not toxic to HepG2 cells.

\section{Leishmanicidal test}

In the leishmanicidal tests, at a concentration of $200 \mu \mathrm{g} / \mathrm{mL}$, the $M$. dubia extract inhibited the growth of L. amazonensis and L. chagasi promastigotes up to $85 \%$ and $30 \%$, respectively. This inference is based on the results obtained from the resazurin assay. The promastigote forms of L. braziliensis continued to proliferate in the presence of the extract (Figure 1).

The M. dubia extract presented greater inhibitory activity against the $L$. amazonensis strain than that against the other two strains of Leishmania, making it possible to calculate a dose response and $\mathrm{IC}_{50}$ values (Table 1). The positive control used in the anti-leishmanial bioassays was pentamidine, possessing $\mathrm{IC}_{50}$ value $=0.21 \mu \mathrm{g} / \mathrm{mL}(0.09)$.

\section{DISCUSSION}

The results of this study show that M. dubia species could be added to the list of Amazonian plants with anti-P. falciparum W2 activity. Meneguetti et al. ${ }^{(26)}$ reported that 76 species of plants distributed throughout 32 families in the Amazon presented antimalarial activity. Twenty six of the plant species mentioned previously showed in vitro activity against 3D7, W2, FcB1, K1, Dd2, D2, D6, F32, FcM29, and Nigerian strains of $P$. falciparum, particularly against $P$. falciparum and contained 66 active compounds.

Borges et al. ${ }^{(27)}$ reported the antioxidant, antibacterial, and antifungal properties of the leaf, bark, and fruit extracts from plants of the Myrciaria genus; these properties are attributable to the presence of several active components including phenolic compounds such as tannins, flavonoids, ellagic acid, and anthocyanins.

Saraiva et al. ${ }^{(28)}$ observed that the Caesalpinia pyramidalis Tull extract showed anti-staphylococcal activity attributable to the presence of quercetin, catechins, ellagic acid, flavonoids, proanthocyanidins, and gallic acid. Rauha et al. ${ }^{(29)}$ showed that pure compounds such as flavone, quercetin, naringenin, morin, and kaempferol inhibited Staphylococcus aureus. Camu-camu fruits present high levels of ellagic acid, tannins, cyanidin, quercetin, catechin, rutin, and kaempferol ${ }^{(11)(12)(30)(31)}$, components that are related to its antimicrobial activity.

Yapu et al. ${ }^{(32)}$ tested aqueous and ethanolic extracts from the peels of M. dubia cultivated in Peru against P. falciparum

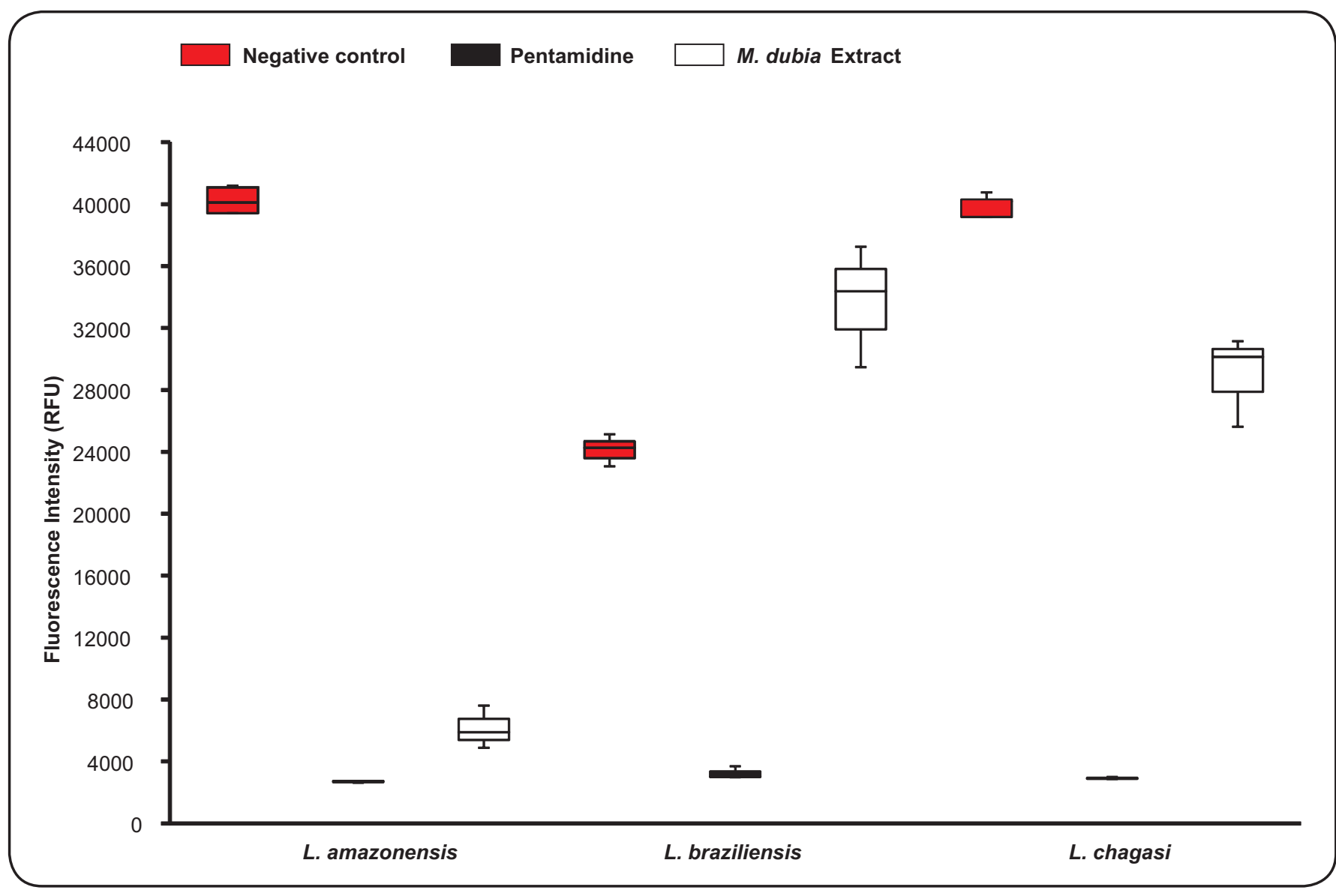

FIGURE 1. Viability of Leishmania spp promastigotes, after treatment with $200 \mu \mathrm{g} / \mathrm{mL}$ of dichloromethanolic extract from Myrciaria dubia and $3 \mu \mathrm{g} / \mathrm{mL}$ of pentamidine, as evaluated using the resazurin method. RFU: relative fluorescence Units; M.: Myrciaria; L.: Leishmania. 
(FCR3 strain resistant to chloroquine), and obtained $\mathrm{IC}_{50}$ values equal to 3 and $6 \mu \mathrm{g} / \mathrm{mL}$, respectively. These values are close to those of other species that have activity against $P$. falciparum, such as Remijia peruviana $\left(\mathrm{IC}_{50}=7.4 \mu \mathrm{g} / \mathrm{mL}\right)$, Cinchona officinalis $\left(\mathrm{IC}_{50}=4.2 \mu \mathrm{g} / \mathrm{mL}\right)$, and Pubescens cinchona $\left(\mathrm{IC}_{50}=\right.$ $1 \mu \mathrm{g} / \mathrm{mL}$ ), and to the value reported for M. dubia leaf extracts, $2.35(1.05) \mu \mathrm{g} / \mathrm{mL}$ in this study.

Colarossi ${ }^{(33)}$ analyzed the cytotoxicity of methanolic extracts from M. dubia seeds and pulp on Jurkat cells (immortalized human $\mathrm{T}$ lymphocytes). The $\mathrm{CC}_{50}$ for the seed extract and pulp extract was $>800 \mu \mathrm{g} / \mathrm{mL}$ and $524.37 \mu \mathrm{g} / \mathrm{mL}$, respectively, indicating that the methanolic extract of $M$. dubia is non-toxic.

Regarding its leishmanicidal potential, the M. dubia extract showed little leishmanicidal activity against $L$. amazonensis, displaying an $\mathrm{IC}_{50}$ value of $190.73(6.41) \mu \mathrm{g} / \mathrm{mL}$. Bezerra et al. ${ }^{(34)}$ analyzed Passiflora edulis (Passifloraceae) and Syzygium jambolanum (Myrtaceae) extracts and observed leishmanicidal activity, as indicated by the $\mathrm{IC}_{50}$ values of 150.1 and $166.6 \mu \mathrm{g} /$ $\mathrm{mL}$, respectively.

The leishmanicidal effect presented by $P$. edulis may be related to the presence of flavonoid and/or terpenoid compounds in the leaves of these plants ${ }^{(35)}$. The extract from the leaves of $S$. jambolanum exhibited a leishmanicidal effect, which could be explained by the presence of saponins and condensed and hydrolysable tannins in the leaves ${ }^{(36)}$.

The SIs obtained in this study for L. amazonensis, L. braziliensis, and L. chagasi were less than 10 . This result does not indicate the absence of antiparasitic activity, rather it shows that a high dose would be required to achieve the desired therapeutic effect ${ }^{(37)}$, which is not feasible. The high $\mathrm{IC}_{50}$ values observed in this study may also be related to the antagonistic effect of other compounds present in the mixture, or to an insufficient amount of the active component responsible for the desired effect. A more detailed analysis of the phytochemical profile of this extract could reveal the existence of purified compounds with potential anti-leishmanial action.

The lack of leishmanicidal activity in inhibition tests against L. braziliensis may be attributed to changes in the genetic sequences responsible for promoting variability between species and phenotypically determining the resistance of these organisms, consequently affecting the efficacy of some compounds $^{(38)}$. L. braziliensis is the most prevalent species in humans and is found in all endemic areas in the country. It is considered the most resistant species to diverse treatments ${ }^{(39)}$.

Genomic plasticity can be observed in the Leishmania genus, which allows for the adaptation of the parasite to diverse environments, including different vertebrate hosts. This plasticity may influence their resistance to therapeutic $\operatorname{drugs}^{(40)}$.

Meneguetti et al. ${ }^{(41)}$ found 32 species of plants in the Brazilian Amazon with leishmanicidal activity distributed throughout 18 botanical families. Of these, 27 presented action against the species L. amazonensis, 6 against L. braziliensis, and 3 against $L$. chagasi.

Among the species studied for activity against $L$. amazonensis, the extracts with the optimal activity were the hexane and the methanolic ones from the leaves of the species Lacistema pubescens, with $\mathrm{IC}_{50}$ values of $3.5 \mu \mathrm{g} / \mathrm{mL}$ and $3.9 \mu \mathrm{g} /$ $\mathrm{mL}$, respectively. Lacistema pubescens possesses antioxidant properties, probably due to the phenolic compounds detected in this species ${ }^{(42)}$, just like M. dubia which possesses these same chemical properties ${ }^{(11)(12)}$.

Many plants have substances belonging to the compound classes alkaloids, terpenes, lignans, chalcones, flavonoids, and sesquiterpene lactones, all described in the literature as having effective leishmanicidal and antiparasitic activity ${ }^{(43)(44)(45)(46)(47)(48)}$. Flavonoids constitute one of the most abundant and widely distributed secondary metabolites in plants. The leishmanicidal activity of this class of metabolites has been observed in L. peruviana, L. braziliensis ${ }^{(49)}$, and $L$. infantum ${ }^{(50)}$.

The action mechanism of flavonoids on Leishmania species was proposed by Mittra et al. ${ }^{(51)}$, who concluded that flavonoids cause apoptosis of the parasite by inducing cleavage of the kinetoplast. Cruz et al. ${ }^{(52)}$ demonstrated that flavonoids, in addition to altering the arrangement of mitochondrial deoxyribonucleic acid (DNA), also inhibit the enzyme arginase, which participates in the parasite's polyamine biosynthesis. Fonseca-Silva et al. ${ }^{(53)}$ demonstrated that treatment of $L$. amazonensis with quercetin, a flavonoid most commonly found in plants, increases the production of reactive oxygen species (ROS), promotes mitochondrial dysfunction in the parasite, and inhibits cell growth.

The leishmanicidal activity evaluated in this study may be related to the presence of both flavonoids and terpenoids in M. dubia, since Franco and Shibamoto ${ }^{(54)}$ analyzed the volatile compounds in camu-camu fruits using gas chromatographymass spectrometry (GC-MS) and identified 21 components. The majority of these were terpenes (98\%), predominantly $\alpha$-pinene (66\%), $d$-limonene (24\%), and $\beta$-caryophyllene (4.6\%).

Meslin et al. ${ }^{(55)}$ reported the involvement of terpenoids in the activation of programmed cell death in Plasmodium species, and in the interference of one or more substances in the process of cell differentiation of the parasite, which has proven to be an extremely complex process, with fine-tuned regulation of gene expression, resulting in a turnover of proteins and destruction of organelles present in Plasmodium, as well as other species of pathogenic protists ${ }^{(56)}$.

To the best of our knowledge, this is the first study to evaluate the action of the dichloromethanolic extract obtained from the leaves of $M$. dubia through bioassays against $P$. falciparum and promastigote forms of L. amazonensis, L. braziliensis, and L. chagasi. This fact highlights the importance of this first report, since the results were satisfactory and contribute to the study of medicinal plants, and the biodiversity of the Amazon.

This study showed that $M$. dubia may be considered an important source for the development of novel drugs for diffuse cutaneous leishmaniasis and malaria treatment, since its extract was active against the parasite $P$. falciparum, presented moderate activity against the promastigote forms of L. amazonensis, and was non-toxic to HepG2 cells in in vitro tests. However, fractionation of the M. dubia extracts, and in vivo testing may help in the elucidation and characterization of 
the chemical compounds responsible for the inhibitory action of these protozoa.

\section{Acknowledgments}

The authors express their gratitude for the technical support from Cristiane Martins Coelho (Lambio/Universidade Federal do Tocantins), Elci Marlei Freitag and Daniel Sol Sol de Medeiros (Fundação Oswaldo Cruz-RO). In addition, we thank our colleagues Rafael Tagori de Melo Cutrim Martins (Doutorado em Biodiversidade e Biotecnologia da Região Norte/UFT) and Alberico Sousa Rocha (UFT) for their assistance in performing sample collections.

\section{Conflict of interest}

The authors declare that there is no conflict of interest.

\section{Financial Support}

This project was supported by the Coordenação de Aperfeiçoamento de Pessoal de Nivel Superior (CAPES), Pró-Amazônia program, Grant number: 23038.010315/2013-66.

\section{REFERENCES}

1. World Health Organization (WHO). World Malaria Report: 2015. 280p. Acessed 2016 March 12. Available at http://www.who.int/ malaria/publications/world-malaria-report-2015/report/en/

2. Pimentel LF, Jácome Júnior AT, Mosqueira VCF, Magalhães NSS. Nanotecnologia farmacêutica aplicada ao tratamento da malária. Rev Bras Cienc Farm 2007; 43:503-514.

3. Ministério da Saúde. Secretaria de Vigilância em Saúde. Departamento de Vigilância Epidemiológica. Guia prático de tratamento da malária no Brasil. Brasília: Ministério da Saúde; 2010.

4. World Health Organization (WHO). WHO Expert Committee on the Control of Leishmaniases. Control of the Leishmaniases: report of a meeting of the Geneva. 22 a 26 March 2010. 186 p. Technical Report $\mathrm{n}^{\text {o: }}$ 949. Acessed 2016 March 12. Available at http://apps.who.int/ iris/bitstream/10665/82766/1/WHO TRS 949 spa.pdf?ua=1/

5. Machado JG, Hoffmann JL, Krause VLK, da Silva AV, Dias-Melicio LA, Langoni H. Cell-mediated immune response to Leishmania chagasi experimental infection of BALB/c immunosuppressed mice. J Venom Anim Toxins Incl Trop Dis 2010; 16:131-146.

6. Costa JML. Epidemiologia da leishmaniase no Brasil. Gaz Med Bahia 2005; 75:3-17.

7. Strobel G, Daisy B. Bioprospecting for Microbial Endophytes and their Natural Products. Microbiol Mol Biol Rev 2003; 67:491-502.

8. van den Berg ME. Contribuição ao seu conhecimento sistemático. 3a . Edição. Belém: Museu Paraense Emílio Goeldi; 2010. 268p.

9. Zanatta CF, Mercadante AZ. Carotenoid composition from the Brazilian tropical fruit camu-camu (Myrciaria dubia). Food Chem 2007; 101:1543-1549.

10. Inoue $T$, Komoda $H$, Uchida $T$, Node $K$. Tropical fruit camucamu (Myrciaria dubia) has anti-oxidative and anti-inflammatory properties. J Cardiol 2008; 52:127-132.

11. de Souza Schmidt Gonçalves AES, Lajolo FM, Genovese MI. Chemical composition and antioxidant/antidiabetic potential of Brazilian native fruits and commercial frozen pulps. J Agric Food Chem 2010; 58:4666-4674.
12. Akter MS, Oh S, Eun JB, Ahmed M. Nutritional compositions and health promoting phytochemicals of camu-camu (Myrciaria dubia) fruit: A review. Food Res Int 2011; 44:1728-1732.

13. Ribeiro SI, Dergan MNB, Mota MGC. Estudo integrado de camucamu (Myrciaria dubia (H.B.K.) McVaugh), frutífera amazônica: nova opção para a valorização econômica dos recursos naturais no Estado do Pará. Belém: 2004. Acessed 2016 March 11. Available at http://www.alice.cnptia.embrapa.br/handle/doc/575338.

14. Santos JC, Santos AP, Rocha CIL. Estrutura da cadeia produtiva de camu-camu no Brasil. Relatório Final de projeto. Belém: Centro de Pesquisa Agropecuária do Trópico úmido (CPATU); 2009. 35p.

15. Myoda T, Fujimura S, Park BJ, Nagashima T, Nakagawa J, Nishizawa M. Antioxidative and antimicrobial potential of residues of camucamu juice production. J Food Agric Environ 2010; 8:304-307.

16. Rosa LH, Queiroz SCN, Moraes RM, Wang X, Techen N, Pan $\mathrm{Z}$, et al. Coniochaeta ligniaria: antifungal activity of the cryptic endophytic fungus associated with autotrophic tissue cultures of the medicinal plant Smallanthus sonchifolius (Asteraceae). Symbiosis 2013; 60:133-142.

17. Trager W, Jensen JB. Human malaria parasites in contínuous culture. Science 1976; 193:673-675.

18. Lambros C, Vanderberg JP. Synchronization of Plasmodium falciparum erythrocytic stages in culture. J Parasitol 1979; 65:418-420.

19. Penna-Coutinho J, Cortopassi WA, Oliveira AA, França TCC, Krettli AU. Antimalarial activity of potential inhibitors of Plasmodium falciparum lactate dehydrogenase enzyme selected by docking studies. PloS One 2011; 6:e21237.

20. Noedl H, Wongsrichanalai C, Miller RS, Myint KSA, Looareesuwan S, Sukthana Y, et al. Plasmodium falciparum: effect of anti-malarial drugs on the production and secretion characteristics of histidinerich protein II. Exp Parasitol 2002; 102:157-163.

21. Reynertson AK, Basile MJ, Kennelly EJ. Antioxidant potential of seven Myrtaceous fruits. Ethnobot Res Appl 2005; 3:25-35.

22. Calvo-Calle J, Moreno A, Eling WM, Nardin EH. In vitro development of infectious liver stages of $P$. yoelii and $P$. berghei malaria in human cell lines. Exp Parasitol 1994; 79:362-373.

23. de Madureira MC, Martins AP, Gomes M, Paiva J, Proença da Cunha A, Rosário V. Antimalarial activity of medicinal plants used in traditional medicine in S. Tomé and Príncipe Islands. J Ethnopharmacol 2002; 8:23-29.

24. Bézivin C, Tomasi S, Lohézic-Le Dévéhat F, Boustie J. Cytotoxic activity of some lichen extracts on murine and human cancer cell lines. Phytomedicine 2003; 10:499-503.

25. Rolón M, Seco E, Vega C, Nogal JJ, Escario JA, Gómez-Barrio A, et al. Selective activity of polyene macrolides produced by genetically modified Streptomyces on Trypanosoma cruzi. Int J Antimicrob Ag 2006; 28:104-109.

26. Meneguetti DUO, Cunha RM, Lima RA, Oliveira FAS, Medeiros DSS, Passarini GM, et al. Antimalarial ethnopharmacology in the Brazilian Amazon. Rev Cienc Farm Basica Apl 2014; 35:577-587.

27. Borges LL, Conceição EC, Silveira D. Active compounds and medicinal properties of Myrciaria genus. Food Chem 2014; 153:224-233.

28. Saraiva AM, Saraiva CL, Gonçalves AM, Soares RR, Mendes FO, Cordeiro RP, et al. Antimicrobial activity and bioautographic study of antistaphylococcal components from Caesalpinia pyramidalis Tull. Braz J Pharm Sci 2012; 48:147-154.

29. Rauha JP, Remes S, Heinonen M, Hopia A, Kähkönen M, Kujala $\mathrm{T}$, et al. Antimicrobial effects of Finnish plant extracts containing flavonoids and other phenolic compounds. Int J Food Microbiol $2000 ; 56: 3-12$. 
30. Reynertson KA, Yang H, Jiang B, Basile MJ, Kennelly EJ. Quantitative analysis of antiradical phenolic constituents from fourteen edible Myrtaceae fruits. Food Chem 2008; 109:883-890.

31. Chirinos R, Galarza J, Betalleluz-Pallardel I, Pedreschi R, Campos D. Antioxidant compounds and antioxidant capacity of Peruvian camu-camu (Myrciaria dubia (H.B.K.) McVaugh) fruit at different maturity stages. Food Chem 2010; 120:1019-1024.

32. Yapu DG, Mozombite DS, Salgado ER, Turba AG. Evaluación de la actividad antiplasmódica in vitro de extractos de Euterpe oleracea, Myrciaria dubia y Croton lechleri. Biofarbo 2008; 16:16-20.

33. Colarossi RVC. Evaluación in vitro del efecto antibacteriano y citotóxico del extracto metanólico de semilla y pulpa de la Myrciaria dubia (camu-camu) sobre cepas de Streptococcus mutans (ATCC 25175) y Streptococcus sanguinis (ATCC 10556). (Tesis) Lima-Peru: Universidad Peruana de Ciencias Aplicadas. Facultad de Ciencias de la salud. Escuela de Odontologia; 2015. 66p.

34. Bezerra JL, Costa GC, Lopes TC, Carvalho IC, Patrício FJ, Sousa $\mathrm{SM}$, et al. Avaliação da atividade leishmanicida in vitro de plantas medicinais. Rev Bras Farmacogn 2006; 16:631-637.

35. Dhawan K, Dhawan S, Sharma A. Passiflora: a review update. J Ethnopharmacol 2004; 94:1-23.

36. Alberton JR, Ribeiro A, Sacramento LVS, Franco SL, Lima MAP. Caracterização farmacognóstica do jambolão (Syzygium cumini (L.) Skeels. Rev Bras Farmacogn 2001; 11:37-50.

37. Davet A, Virtuoso S, Dias JFG, Miguel MD, Oliveira AB, Miguel OG. Atividade antibacteriana de Cereus jamacaru DC, Cactaceae. Rev Bras Farmacogn 2009; 19:561-564.

38. Carneiro JNP, Albuquerque RS, Leite NF, Machado AJT, Brito DIV, Rolón M, et al. Avaliação da atividade tripanocida, leishmanicida e citotóxica do geraniol e citronelal. Cad Cult Cienc 2015; 13:29-36.

39. Name RQ, Borges KT, Nogueira LSC, Sampaio JHD, Tauil PL, Sampaio RNR. Clinical, epidemiological and therapeuthic study of 402 patients with American cutaneous leishmaniasis attended at University Hospital of Brasilia, DF, Brazil. An Bras Dermatol 2005; 80:249-254.

40. Rogers MB, Hilley JD, Dickens NJ, Wilkes J, Bates PA, Depledge DP, et al. Chromosome and gene copy number variation allow major structural change between species and strains of Leishmania. Genome Res 2011; 21:2129-2142.

41. Meneguetti DUO, Lima RA, Macedo SRA, Barros NB, Facundo JB, Militão JSLT, et al. Plantas da Amazônia brasileira com potencial leishmanicida in vitro. Rev Patol Trop 2015; 44:359-374.

42. Silva JM, Motta EVS, Mendes R, Scio E. Caracterização fitoquíımica e avaliação da capacidade antioxidante de diferentes partições de Lacistema pubescens Mart. HU Revista 2011; 37:342-347.

43. Rocha LG, Almeida JRGS, Macêdo RO, Barbosa-Filho JM. A review of natural products with antileishmanial activity. Phytomedicine 2005; 12:514-535.
44. Teles CBG, Moreira LS, Silva AAE, Facundo VA, Zuliani JP, Stábeli RG, et al. Activity of the Lupane isolated from Combretum leprosum against Leishmania amazonensis promastigotes. J Braz Chem Soc 2011; 22:936-942.

45. Begum S, Ayub A, Qamar Zehra S, Shaheen Siddiqui B, Iqbal Choudhary M, Samreen S. Leishmanicidal Triterpenes from Lantana camara. Chem Biodivers 2014; 11:709-718.

46. Silva AAS, Morais SM, Falcão MJC, Vieira IGP, Ribeiro LM, Viana SM, et al. Activity of cycloartane-type triterpenes and sterols isolated from Musa paradisiaca fruit peel against Leishmania infantum chagasi. Phytomedicine 2014; 21:1419-1423.

47. Bernal FA, Coy-Barrera E. In-silico analyses of sesquiterpenerelated compounds on selected Leishmania enzyme-based targets. Molecules 2014; 19:5550-5569.

48. Teles CBG; Moreira-Dill LS, Silva AA, Facundo VA, de Azevedo Jr WF, Silva LHP, et al. A lupane-triterpene isolated from Combretum leprosum Mart. fruit extracts that interferes with the intracellular development of Leishmania (L.) amazonensis in vitro. BMC Complement Altern Med 2015; 15:1-165.

49. Marín C, Boutaleb-Charki S, Diaz JG, Huertas O, Rosales MJ, Pérez-Cordon G. Antileishmaniasis activity of flavonoids from Consolida oliveriana. J Nat Prod 2009; 72:1069-1074.

50. Ramírez-Macías I, Marín C, Díaz JG, Rosales MJ, GutiérrezSánchez R, Sánchez-Moreno M. Leishmanicidal activity of nine novel flavonoids from Delphinium staphisagria. Sci World J 2012; 2012:203646. doi: 10.1100/2012/203646.

51. Mittra B, Saha A, Chowdhury AR, Pal C, Mandal S, Mukhopadhyay S, et al. Luteolin, an abundant dietary component is a potent anti-leishmanial agent that acts by inducing topoisomerase II-mediated kinetoplast DNA cleavage leading to apoptosis. Mol Med 2000; 6:527-541.

52. Cruz EM, da Silva ER, Maquiaveli CC, Alves ESS, Lucon Jr JF, dos Reis MB, et al. Leishmanicidal activity of Cecropia pachystachya flavonoids: Arginase inhibition and altered mitochondrial DNA arrangement. Phytochemistry 2013; 89:71-77.

53. Fonseca-Silva F, Inacio JDF, Canto-Cavalheiro MM, Almeida-Amaral EE. Reactive oxygen species production and mitochondrial dysfunction contribute to quercetin induced death in Leishmania amazonensis. PloS One 2011; 6:e14666. doi: 10.1371/journal.pone.0014666.

54. Franco MRB, Shibamoto T. Volatile composition of some Brazilian fruits: Umbu-caja (Spondias citherea), camu-camu (Myrciaria dubia), Araca-boi (Eugenia stipitata), and Cupuacu (Theobroma grandiflorum). J Agric Food Chem 2000; 48:1263-1265.

55. Meslin B, Zalila H, Fasel N, Picot S, Bienvenu A-L. Are Protozoan metacaspases potential parasite killers? Parasit Vectors 2011; 4:26. doi:10.1186/1756-3305-4-26.

56. Duszenko M, Ginger ML, Brennand A, Gualdrón-López M, Colombo M-I, Coombs GH, et al. Autophagy in protists. Autophagy 2011; 7:127-158. 